\title{
Caliphate; is it Theological Inevitability or Sociological Experimentation?
}

\author{
M. Ilham, ${ }^{1}$ Abdul Syatar, ${ }^{2}$ Muhammad Majdy Amiruddin ${ }^{3}$ \\ ${ }^{1}$ Institut Agama Islam Negeri Palopo, Indonesia \\ ${ }^{2}$ Universitas Islam Negeri Alauddin Makassar, Indonesia \\ ${ }^{3}$ Institut Agama Islam Negeri Parepare, Indonesia \\ m.ilham@iainpalopo.ac.id
}

\begin{tabular}{c}
\hline Article \\
Information \\
\hline
\end{tabular}

Received: February 17, 2021

Revised 1: February 27, 2021

Revised 2: June 01, 2021

Accepted: June 28, 2021

Keywords

Khilafah, Public Reason, Social Experimentation
Kata Kunci

Khilafah, Nalar Publik, Eksperimen Sosiologis

\section{Abstract}

The main objective of this study was to investigate the ontological status of the caliphate as a sociological experimentation. The study was a library research which adopted a descriptive analytical method through reading various literatures with a philosophical historical approach. The data were obtained from a variety of credible literature and other various supporting information then presented with a strong analytical instrument based on the normative foundation and thoughts of the figures to generate a deeper elaboration of ideas. The result showed that the relationship between religion and the state was a matter of pure contact with public reason. The absence of religious sharih texts in state matters, including models and singular forms of state practice, is an indisputable reason for the profanity of the Khilafah. The state practices exemplified by the Prophet and Companions were nothing more than sociological experiments. The experiment of the Prophet and purely sociological relative is not a theological necessity. The state is in principle an institution designed to realize benefit as the highest moral principle and locus of the view of the universal will. As an alternative to the caliphate model which is outdated and impossible to revive, a democratic state is a realistic choice because it is in accordance with the development of modern life and is an effort to approach universal human values

\section{Abstrak}

Artikel ini bertujuan mengurai status ontologis khilafah sebagai produk sosial. Artikel ini merupakan riset kepustakaan yang menggunakan metode deskriptif analitis melalui pembacaan terhadap berbagai literatur dengan pendekatan historis filosofis. Sumber data diperoleh 
dari berbagai literatur yang kredibel dan berbagai informasi pendukung lainnya, kemudian disajikan dengan instrumen analisis yang kuat berdasarkan landasan normatif dan pemikiran para tokoh, sehingga melahirkan elaborasi gagasan yang lebih mendalam. Hasil penelitian menunjukkan bahwa khilafah sebagai produk pengalaman hisoris bernegara umat Islam tidak dapat dipahami sebagai sebuah keniscayaan teologis yang bersifat rigid melainkan eksperimen sosiologis yang terbuka terhadap berbagai pemahaman baru untuk merealisasikan kemaslahatan sebagai prinsip moral tertinggi negara. Absennya teks-teks otoritatif keagamaan berkaitan dengan model dan bentuk tertentu praktik kenegaraan menegaskan bahwa negara tidak terikat apalagi dipaksakan dengan satu model tertentu. Format dan praktik kenegaraan yang dicontohkan Nabi dan sahabat bukanlah sebuah keniscayaan teologis semata, melainkan kebutuhan historis dalam merespon tuntutan dinamika zaman

\section{Introduction}

The polemic on the existence of the concept of the state in Islamic authoritative texts caused opposition among Muslim thinkers. After the collapse of the Ottoman Empire in 1924 AD, the caliphate reaped a prolonged polemic. Muslims are not unanimous about the idea of the caliphate. In contrast, the caliphate becomes an actual issue that is never finished and ended.

The controversy around the caliphate colored the long journey of Muslim thought to this day. Some circles still want while some others refuse. At the theoretical level, the caliphate is indeed ideal because it is projected to unite the Islamic world, but sociologically it is not easy to realize it in the political order of the modern state. ${ }^{1}$

Islamic fundamentalist groups consider the caliphate as a necessity in the political dimension of Islam. The group has aspirations to form supranational and transnational leadership systems. This group believes that in the political arena, Islam teaches an integral state system with its teachings. ${ }^{2}$ Therefore, giving birth to jargon

"Mabroer Irwan, "Rekonstruksi Khilafah Dalam Al-Qur'an," Al-Fanar: Jurnal Ilmu Al-Qur'an dan Tafsir 1, no. 1 (2018): 91-106.

${ }^{2}$ Ija Suntana, Pemikiran Ketatanegaraan Islam, first edition (Bandung: Pustaka Setia, 2010), 16-17. for them namely al-Islam; din wa daulah (Islam; Religion and Country). ${ }^{3}$

In addition, the slogan and jargon "it is time for the caliphate to lead the world with sharia" also shows the ideals to realize their demands so that the form of a state with a model of caliphate and the implementation of a state or government are based on Islamic law. For them, living the caliphate is the duty of Muslims because it is the starting point of the Islamic people's awakening from adversity. ${ }^{4}$

The argument for the caliphate advocates is built on the claim that Islamic law cannot be separated from the construction of a state. The caliphate's trace is considered to have originated from the Prophet Adam's figure as khalifatullah $f i$ al-ardh. Excluding religion from the framework of the state is a form of modern jahiliyyah.

Islam has relevant characteristics to the context of space and time (salih li kull zaman wamakan), which makes the teachings will still exist, progress and influence in the political system. In essential, Islam does not depend entirely on politics and politics does not depend

\footnotetext{
${ }^{3}$ Ahmad Suaedy (Ed.), Pergulatan Pesantren Demokrasi (Yogyakarta: LkiS, 2000), 88.

${ }^{4}$ Muhammad Imarah, Izalah Al-Syubhat 'an Ma'ani Al-Musthalahat
} (Kairo: Dar al-Salam, 2010), 388. 
on the teachings of Islam. Islam and politics should go hand in hand because they are an integral part of life that cannot be separated from the dynamics of political culture. ${ }^{5}$

Bearers of the idea of the caliphate place all alternative forms and other considerations as a theological violation. Various ideological normative arguments were submitted to reinforce the obligation to enforce the caliphate. Theocracy is believed to be an ideal form of state. Religion as regulator of the state and state is an embodiment of the absolute will of the divine. ${ }^{6}$

However, other Islamic groups believe that the caliphate is not a theological necessity, but a sociological-relativist experiment. Unlike the first group, this last group views the state as an institution designed to realize benefit as the highest moral principle and locus of the view of the universal will. ${ }^{7}$

Based on the description, the caliphate as part of the political experience of the Muslim community has a number of problems, especially related to the discourse and praxis of the modern state. ${ }^{8}$ In Indonesia, the propaganda of Islamic law as a law and a state system replaces the constitution takes the form of cultural movements and negotiations and manifests as a political movement.

Despite its ideological nature, Islamic fundamentalism exists as a globalizing force that campaigns for a religious state in the form of a caliphate as the ideal concept of a state, complete with laws that apply universally. Various attempts were made to promote the idea of a caliphate in Indonesia.

In this sense, the idea of a caliphate contains

${ }^{5}$ Fajar Syarif, "Politicization of Religion: Religion in Political Discourse". Walisongo: Jurnal Penelitian Sosial Keagamaan, no. 2 (2017): 443.

${ }^{6}$ Ibid., 445.

${ }^{7}$ Wasisto Raharjo Jati, “Agama Dan Politik: Teologi Pembebasan Sebagai Arena Profetisasi Agama". Walisongo: Jurnal Penelitian Sosial Keagamaan, no. 1 (2014): 133-156.

${ }^{8}$ Fatni Erlina, "Sistem Khilafah Islamiyah Dalam Perspektif Ketatanegaraan Republik Indonesia," Jurnal Idea Hukum, no. 1 (2019). several fundamental problems related to the initial portrait of religion's discourse and the state in Islam. Ideological legitimacy and claims regarding the concept of a caliphate and the caliphate's position between absolute theological necessity or simply sociological experimentation that is temporally local.

This research is a literature study and uses a descriptive analytical method by looking at the facts and using a historical philosophical approach. Primary data were obtained from various credible and up-to-date literatures, such as reputable books and journals. Secondary data were founded from supporting information such as websites. Afterwards, it was presented with a strong analytical instrument based on normative texts and the thoughts of the figures so that it creates a deeper elaboration of ideas.

\section{Questioning the Ontological Status of the Caliphate: A Portrait of Religion and State Relations}

Religion and state relations are often suggested as two opposing entities. The relationship of aldunya wa al-din (the world and the hereafter) is one of the examples. The traces of these two technical terms can be traced both in the Qur' an and Sunnah so as to inspire the birth of the expression al-Islam huwa al-din wa al-daulah. ${ }^{9}$ An expression that describes a fairly strong link between religion and the state in the construction of religious texts.

This phenomenon can be understood considering the two main sources of Islamic teachings, namely the Qur'an and the Sunnah contain a number of basic principles that become a reference in regulating individual relations and society. Additionally, this perception also refers to the practice of history. ${ }^{10}$

The variety of terms are often associated and understood as political concepts, state and power such as the caliphate, dawlah, ulil amr or hukumah

\footnotetext{
${ }^{9}$ Ahmad Suaedy, Pergulatan Pesantren Demokrasi, 88. ${ }^{10}$ Abdul Aziz, Chiefdom Madinah: Salah Paham Negara Islam (Jakarta: Pustaka Alvabet, 2011), 1.
} 
and other technical terms place them in the zhanniyyat region so as to open up opportunities for the birth of various interpretations and claims. ${ }^{11}$

The historical experiences show casing diverse models and practices of power. Therefore, it is not surprising that the relationship between religion and the state is a problem that preoccupies many Muslim intellectuals. ${ }^{12}$

The polarization of Islamic understanding about the state is indeed due to the state or politics is indeed a very complex and conflicting region, so the theological dimension is intertwined with ideological aspects and practical interests and involves competition, including in interpreting Islamic symbols and teachings. ${ }^{13}$ In fact of the historical landscape of Islam, politics was a theological problem emerged and born from the womb of Muslim politics.

The existence of the caliphate is often claimed as a representation and the only way for Muslims towards goodness. However, the issue of the caliphate which is believed to be an ideal political institution of Muslims is not devoid of contradiction. In fact, the issue of caliphate is the forerunner of the division of Muslims into various religious frictions. The fact of the division of Muslims in dealing with the issue of caliphate often gives rise to the impression that the caliphate is no more than an ideal idea with

\footnotetext{
${ }^{11}$ Yusdani, Fiqh Politik Muslim: Doktrin, Sejarah Dan Pemikiran (Yogyakarta: Amara Books, 2011), 2.

${ }^{12}$ There are a series of Islamic theorists who represent classical times such as Syihabuddin Ahmad Bin Abi al-Rabi 'which is popularly known as Ibn Abi Rabi' (d. 885 M/272 H), Abu Nashir al-Farabi (870-950 M/257-339 H ). In the Middle Ages represented by Abu Hasan 'Ali Bin Habib al-Mawardi (976-1059 M/364-450 H), Abu Hamid al-Ghazali (1058-1111 M/ 450-505 $\mathrm{H})$ and Abu' Abbas Ahmad bin 'Abdul Halim which is popularly known as Ibn Taymiyyah (1263-1329 M/661-728 H). While in the modern era were represented by Jamaluddin al-Afghani (1838-1897 AD) and Muhammad Rasyid Ridha (1865-1935 AD), Sayyid Qutb (1906-1966 AD), and Abu A'la al-Maududi (1903-1979 AD). Sukron Kamil, Pemikiran Politik Islam Tematik, first edition (Jakarta: Kencana, 2013), 21. Abdul Aziz, Chiefdom Madinah: Salah Paham Negara Islam, 1.

${ }^{13}$ Haedar Nashir, Islam Syariat: Reproduksi Salafiyah Ideologis Di Indonesia, first edition (Bandung: Mizan, 2013), 140.
}

an empty reality. ${ }^{14}$

Fitnah Kubra, ${ }^{15}$ is an example of the dark portrait of Muslim politics. History records it as a bloody event involving internal Muslims starting from a dispute between Talhah, Zubair and 'Aisha and Ali Bin Abi Talib, to the dispute between $\mathrm{Mu}$ 'awiyah and the Shiites, Khawarij followers and supporters of the Abbasid Dynasty. ${ }^{16}$

It was remarked that in the early period of Islamic history, especially in the middle of the 7th century $\mathrm{AD}$, closeness to political authority was seen as something that could bring disaster. It is because violent means often become a mechanism for consolidating power. ${ }^{17}$

Political battles among Muslims to fight for power that occurred since the beginning of the first century Hijriah and subsequent periods were also colored by disputes of religious understanding, especially regarding the legitimate and ideological foundation against the authorities. The religious formulations developed tend to maintain the status quo. ${ }^{18}$

The political context causes all forms of rejection of the idea of forming a caliphate as a sin and is a rebellion against Islamic axiomatic teachings. ${ }^{19}$ With regard to the question of the legitimacy of power, the form of the caliphate state is claimed as a sacred and sacred constitutional format.

\section{Caliphate and Ideological Legitimacy: Lawsuit and Defense of the Caliphate Idea}

In the modern era, religious and state discourse re-surfaced and seized the attention of a number

\footnotetext{
${ }^{14}$ Luthfi Assyaukanie, Ideologi Islam Dan Utopi: Tiga Model Negara Demokrasi Di Indonesia (Jakarta: Freedom Institute, 2011), 64 .

${ }^{15} \mathrm{Abu}$ al-Fath Abdul Karim bin Abi Bakr Ahmad al-Syahrastani, Al-Milal Wa Al-Nihal, Vol. I (Beirut: Dar al-Ma'arif, 1975), 24.

${ }^{16}$ A. Aziz, "Khilafah Dan Negara-Bangsa: Pertarungan Legitimasi Yang Belum Usai," SIASAT 3, no. 2 (2019): 24-36.

${ }^{17}$ Ahmet T. Kuru, Islam, Otoritarianisme, Dan Ketertinggalan (Jakarta: Kepustakaan Populer Gramedia, 2020), 5.

${ }^{18}$ Jejen Jaelani, "Kontroversi Khilafah: Islam, Negara, Dan Pancasila," Jurnal Sosioteknologi 14, no. 2 (2015).

${ }^{19}$ Abdul Aziz, Chiefdom Madinah: Salah Paham Negara Islam, 92-93.
} 
of Muslim political observers. The position of Islam in the modern political system is questioned again. In other words, Is Islam compatible with the idea of a nation state or not?

The lawsuit and defense of the caliphate as the sole and ideal form of the state among Muslim thinkers has strengthened along with its contact with the idea of nationalism. The problem is increasingly complicated, especially when faced with the fact that the concept of the state, especially the nation-state is a modern concept which is a Western product that has no precedent in the historical experience of Muslims..$^{20}$

Although the tension between the caliphate's thinking and nationalism had different intensities between one region and another, Western colonialism in the 18-20 th century that led to the collapse of the Ottoman Empire was not denied as a factor that contributed to the birth of debate between modernists and traditionalists. ${ }^{21}$ The tension between the thoughts of the Caliphate and nationalism has different intensities between one region and an other according to the historical experience of Muslims themselves in each.

Since Mustafa Kemal Ataturk, the father of modern Turkey shifted the caliphate proclaimed secularism as a promising alternative system. The issue of separation of religion and state caused quite serious controversy. The authenticity of absolute monarchical power was sued. Indeed, it reaps a variety of critical responses among Muslims.

In general, Muslim reactions to the issue of the caliphate reactive. The reason is not only because the closure of the caliphate is contrary to the religious-political doctrine that they believe but also because the alternative proposed - namely secularism - is a Western product still considered as an enemy. ${ }^{22}$

\footnotetext{
${ }^{20}$ Rikza Muqtada, "Utopia Khilāfah Islāmiyyah: Studi Tafsir Politik Mohammed Arkoun," Jurnal Theologia 28, no. 1 (2017): 145-164.

${ }^{21}$ Yusdani, Fiqh Politik Muslim: Doktrin, Sejarah Dan Pemikiran, 3. ${ }^{22}$ Luthfi Assyaukanie, Ideologi Islam Dan Utopi: Tiga Model Negara Demokrasi Di Indonesia, 38.
}

The controversy surrounding the caliphate in that period was colored by a debate between two students of Muhammad 'Abduh: Rasyid Ridha (1865-1935) and 'Ali 'Abd al-Raziq (1888-1966). ${ }^{23}$ Ridha believes that the caliphate is not merely a utopia but has an empirical rest in the historical experience of Muslims. Thus, the obligation of Muslims to realize an Islamic state. Ridha believes that the Prophet Muhammad was not just a messenger of divinity but rather a messenger of authority.

Sayyid Qutb suggested that Muslims should do a total rejection of the nation state which is a product of modernity because it is considered to reduce God's sovereignty. Human domination must be returned solely to God. ${ }^{24}$

Further, Qutb even reflected that the peaceful teachings brought by Islam did not mean the prohibition of attacking in the context of eliminating all forms of the jahiliyyah system. According to Qutb, Muslims should maximize the control around the world to assert God's sovereignty and remove all human-made laws.

Mawardi also confirmed the authority of religion regarding public morality. In interpreting the comprehensive Islamic concept and amar makruf nahi munkar, Mawardi seems to legalize authoritarianism with the religious police instrument. $^{25}$

Yusuf al-Qardhawi is also a figure who strongly opposes the view of religion-state separation. He noted that it is pragmatic because it does not provide the existence of religion in the political sphere. The existence of religion in political space does not have a negative impact on the state or religion itself. In contrast, the presence of religion in the political sphere serves as a guide

\footnotetext{
${ }^{23}$ Muhammad Imarah, Al-Islam Wa Ushul Al-Hukm Li 'Ali 'Abd Al-Raziq, Vol. II (Beirut: al-Mu'assasah al-'Arabiyyah li alDirasat wa al-Nasyr, 1988), 160.

${ }^{24}$ M. Muhsin Jamil, Membongkar Mitos Menegakkan Nalar "Pergularan Islam Liberal Versus Islam Literal (Yogyakarta: Pustaka Pelajar, 2005), 109.

${ }^{25}$ Ahmet T. Kuru, Islam, Otoritarianisme, Dan Ketertinggalan, 81.
} 
for the good. Removing religion from politics is the same as breaking down the pillars of goodness and the foundation of piety. ${ }^{26}$

'Abd al-Karim Zaidan proposed a historical analysis in explaining the concept of the state in Islam. He quoted the statement of the Holy Prophet. In the Bai'at-Aqabah II, incident was evidence of preparations for the formation of an Islamic state. It was mentioned in the hadith:

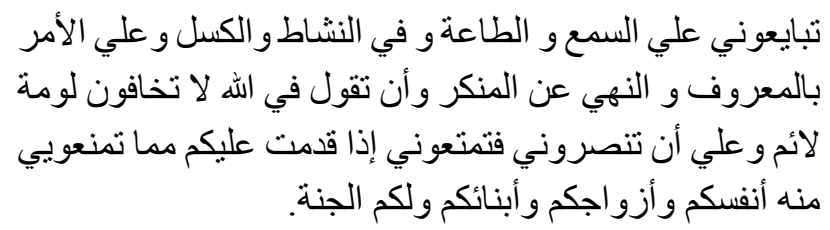

'Abd al-Karim Zaidan in his conclusion stated that the oath of allegiance was a form of social contract between Muslims and the Prophet as a preliminary preparation for the establishment of an Islamic state. This can be understood as the transfer of power to the Holy Prophet. To carry out state authority, Muslims are mandatory to provide support and contribute to defend the country according to the principle of amar ma 'ruf nahi munkar. ${ }^{27}$

A similar analysis was developed by Yusuf Musa. ${ }^{28}$ According to him, the Bai'at-Aqabah II incident was a precedent for the idea of a state formation when the Prophet was still domiciled in Mecca. This event is strong evidence that from the beginning the Prophet (saw) made the formation of the state part of the prophetic mission.

Although the Hijrah event was the starting point that led the Prophet to the new phase of his life and in that phase, the Prophet paid serious attention to the formation of an organization that could handle the various problems

\footnotetext{
${ }^{26}$ Yusuf Al-Qardhawi, Al-Din Wa Al-Siyasah: Ta shil Wa Radd Syubuhat (Kairo: Dar al-Syuruq, 2007), 79.

${ }^{27}$ H.A Djazuli, Fiqh Siyasah: Implementasi Kemaslahatan Umat Dalam Rambu-Rambu Syariah (Jakarta: n.d.).

${ }^{28}$ Muhammad Yusuf Musa, Nizham Al-Hukmi Fi Al-Islam: AlImamah Wa Riyasah Al-Ummah Wa Ma Yata'allaq Biha Min Buhuts (Kairo: Dar al-Fikr al-‘Arabi, n.d.), 15-16.
}

encountered, ${ }^{29}$ Yusuf Musa rejected the claim that the authority of the Prophet in the Mecca period was different from the authority of the Prophet when he was in Medina. The change in the $d a$ 'wah pattern does not mean the dualism of the Prophet's personality as religious and state leaders. ${ }^{30}$

Although the political potential contained in the early revelations of Islam at that time could not be realized yet, Muhammad's recognition as a bearer of truth treatises originating from God was considered a potential basis for religious interference in political matters. ${ }^{31}$ That can be understood because the contents and religious ideas that are preached are a direct response to the unequal socio-economic situation of life at that time. ${ }^{32}$

For the supporters of the caliphate, the claim that portrays the Prophet Muhammad as a religious leader and does not have the authority as the leader of the state is a claim that was born

\footnotetext{
${ }^{29}$ Asghar Ali Engineer, Islam and Its Relevance to Our Age, Translated by Hairus Salim HS with the title Islam Dan Pembebasan, first edition (Yogyakarta: Pustaka Pelajar, 2000), 19. Interestingly, the Madinah community is a pluralistic society both in terms of race and religion. The inhabitants of Medina included a mixture of Jewish, Arabic races mainly affiliated to the Aus and Khazraj tribes, as well as Muslim immigrants from Mecca. This fact shows that the heterogeneity of Madinah society at that time had similarities with modern society in secular countries. A country with a diversity of races, ethnicities and religions was united under the leadership of the Prophet and that is called the ummapp. This fact also shows that between the Prophet and the inhabitants of Yastrib (Medina) a partnership was formed to reach an agreement to protect and protect one another's mutual safety. Baiat given by representatives of the population of Medina to the Prophet Muhammad can be interpreted as a mandate to the Prophet to lead and govern the city of Medina. The Prophet's position in Medina with such a mandate has established him as a head of state. If examined closely, the process of appointing the Prophet to the position of head of state, in the sense of modern politics, has fulfilled the requirements.

${ }^{30}$ Ahmad Musyafiq, "Spiritualitas Kaum Fundamentalis," Walisongo: Jurnal Penelitian Sosial Keagamaan 20, no. 1 (2012): 55-78.

${ }^{31}$ Moch. Qasim Mathar, Politik Islam Dalam Sorotan: Ketegangan Antara Pemikiran Dan Aksi, first edition (Makassar: Alauddin University Press, 2012), 2.

${ }^{32}$ Tuti Munfaridah, "Kepemimpinan Dalam Islam," Wahana Akademika: Jurnal Studi Islam dan Sosial 14, no. 1 (2016).
} 
from a false reading of history. He also rejected the unsophisticated view that the Prophet's religious movements did not have real political relevance. Similarly, the claim which states that the formation of a state crossed the mind of the Holy Prophet. ${ }^{33}$

This view was shared by some Orientalist scholars. They believed that the teachings of Islam were not merely religious, but also regulated the problems of the state. This view could be traced in the expression C.A. Nollino said that "Muhammad laid the foundation of religion and state at the same time". ${ }^{34}$

D. B. Macdonald also called Madinah as the first Islamic state to have laid political foundations for Islamic legislation. ${ }^{35}$ This view confirmed that in the Medina state, the Prophet not only acted as a religious leader, but also as the head of state. Therefore, the Prophet's political actions are often appointed as the starting point for the establishment of political organizations in Islamic history. A similar view is also found in H. R. Gibb's view. He asserted that Islam is not merely a personal-individual creed, but also demands the creation of a society that has a system of organizing the government and specific rules of law. ${ }^{36}$

The group of bearers of the caliphate actually did not dismiss the long debate that colored the relations of religion and the state. It means that the formation of a social institution of Muslims in Medina is also an undeniable fact.

In this context, Sheikh Mahmud Syaltut concluded that it was very difficult to draw a line of demarcation between religious and state

\footnotetext{
${ }^{33}$ Syarif, "Politicization of Religion: Religion in Political Discourse". Walisongo: Jurnal Penelitian Sosial Keagamaan, no. 2 (2017): 448.

${ }^{34}$ Muhammad Yusuf Musa, Nizham Al-Hukmi Fi Al-Islam: AlImamah Wa Riyasah Al-Ummah Wa Ma Yata'allaq Biha Min Buhuts, 17.

${ }^{35}$ Syamsuddin Radjab, Syariat Islam Dalam Negara Hukum (Makassar: Alauddin University Press, 2011), 28.

${ }^{36}$ Muhammad Yusuf Musa, Nizham Al-Hukmi Fi Al-Islam: AlImamah Wa Riyasah Al-Ummah Wa Ma Yata'allaq Biha Min Buhuts, 14.
}

territories. He also argued that it is impossible to imagine Islam without community organizing and state policies in it. Religion is the principle of state that directs social behavior. Sheikh Mahmud Syaltut revealed, ${ }^{37}$

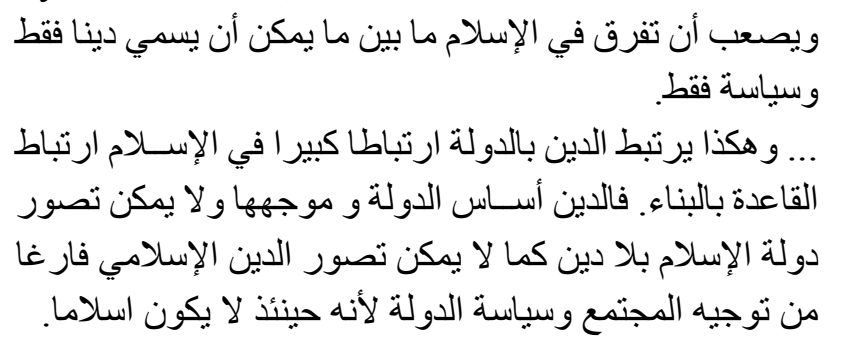

Meanwhile 'Ali' Abd al-Raziq considers that the caliphate is only one of a variety of alternative government systems. Prophet Muhammad was sent by God not as a political leader but as an apostle. 'Abd al-Raziq considered politics not the true aim of the prophetic mission. What Islam is concerned about is not a form of government; republic, kingdom, or caliphate but how does a government in practice implement universal Islamic values such as justice.

'Ali' Abd al-Raziq himself does not specifically use the terminology of secularism. The argument put forward by Abd al-Raziq from al-Qur'an and hadith is explicitly put forward to justify the idea of separation of religion and state. Among them, al-Nahl: 64; al-Isra': 105; al-Nur: 54; al-'Ankabut: 18; al-Ahzab: 45; Fathir: 23; Yasin: 73; dan Shad: 65. ${ }^{38}$

'Abd al-Raziq also quoted the popular phrase which says "give to the Emperor what is the Emperor's right and to God what is God's right" ${ }^{39}$ as justification for the different functions of religion and state.

Al-Raziq argued that the Prophet Muhammad left Medina without any explanation regarding the form of government of the Muslims. There is no clarity whether the idealized state form is global

\footnotetext{
${ }^{37}$ Mahmud Syaltut, Min Taujihat Al-Islam (Kairo: Dar al-Syuruq, 2004), 447.

${ }^{38}$ Muhammad Imarah, Al-Islam Wa Ushul Al-Hukm Li 'Ali 'Abd Al-Raziq, 173.

${ }^{39}$ Ibid., 115.
} 
in the context of a nation state or only a city state..$^{40}$

Al-Raziq's claim asserts that the commission of each prophet was intended as an apostle and not a political leader. According to him, the emphasis in Islam is not the format or form of government, but the application of universal Islamic values. ${ }^{41}$

Thaha Husein also criticized the opinion stated that theocracy is a model of the state practiced by the Prophet. The opinion is considered as a no basis statement. ThahaHusein submitted a QS. 'Ali 'Imran: 159 about the command to the Holy Prophet to carry out musyarawah, exchanging ideas regarding their affairs. Furthermore, Thaha Husein asserted that if everything was based on heaven's decision, then there was no point in the order to deliberate. ${ }^{42}$

In fact, the second group views the caliphate as something profane because they totally reject the theological perspective in seeing the caliphate.

Polarization and religion certainly show that Islam as a way of life, does not have a clear concept of the state, including the question of how the state is created and maintained. Islam does not have a clear and firm perspective on the mechanism of leadership change after the death of the Prophet Muhammad.

\section{Caliphate: Sociological Experimentation Is Not Theological Inevitability}

The relation between the state and religion was inspired by the rather awkward relationship between Islam as a religion (din) and the state (dawlah). The religious and state discourse gave birth to various experiments to harmonize the din with the concepts and political culture of Muslim societies. Moreover, this is supported by the fact that religious texts (al-Qur'an and Sunnah) do

\footnotetext{
${ }^{40}$ M. Syafi'i Anwar, Memperkuat Substansi Islam "Pengantar" Dalam Abdurrahman Wahid, Islamku, Islam Anda, Islam Kita “Agama Masyarakat Negara Demokrasi," first edition (Jakarta: The Wahid Institute, 2006), xviii.

${ }^{41}$ Muhammad Salim Al-'Awwa, Fi Al-Nizham Al-Siyasi Li AlDawlah Al-Islamiyyah (Kairo: Dar al-Syuruq, 2008), 116.

${ }^{42}$ Thaha Husayn, Al-Fitnah Al-Kubra, Utsman (Kairo: Dar alMa'arif, n.d.), 23.
}

not have explicit information about the state and government. ${ }^{43}$

Therefore, interpretations of religious texts find momentum in producing normative claims of state ideology. Instead, interpretations of historical experience contribute to normative claims about power models and practices. ${ }^{44}$

In fact, the integration between religion and state in the doctrine of al-Islam huwa al-din wa al-daulah opens the opportunity for harmonious dialogue between Islam as a religion and politics so that it is not trapped into the cliff of conflict between the two.

The existence of Islamic doctrine as a religion and a state is an effort to integrate the permanent and temporal profane areas that are believed by Muslims. In a historical perspective, this doctrine was formulated as a counter concept to the Christian theological system which was once a political rival - not theology - in the history of power in the world. ${ }^{45}$

However, the doctrine of al-Islam huwa aldin wa al-daulah does not mean that the state as God's representative is automatically sacred and is a representation of God's absolute will on earth. Actually, the historical experience of Muslims shows the practice of mixing between religious and political (state) character in implementing the doctrine.

This confusion is also responsible for the disasters that befall Muslims both in politics and religion. In the religious field, this mixture is responsible for the divisions between Sunnis and Shiites whose main source is politics. The Shiffin War is an internal conflict of Muslims which contributed to the birth of two large groups, Sunni (Sunnah) and Shia.

In the political sphere, this mixing opened the way for the authorities to legitimize their claims to the caliphate and perpetuate power. The lord

\footnotetext{
${ }^{43}$ Azyumardi Azra, Pergolakan Politik Islam (Jakarta: Paramadina, 1996), 1.

${ }^{44}$ Ija Suntana, Pemikiran Ketatanegaraan Islam, 21.

${ }^{45}$ Ibid., 17.
} 
is imaged as the shadow of God on earth (the shadow of God in the earth/zhillullah fi al-ardh). God's rights are attributed to the authorities so that each of his policies is seen as a representation of the heavenly command that must be obeyed. In this case, power is a necessity that is inherent automatically, not because of the qualifications and quality of leadership. ${ }^{46}$

The theology of the caliphate and the Islamic state places the ruler as a holy figure who never makes mistakes. Absolute submission and loyalty to the leader is positioned as another form of theological belief about God's sovereignty. At this point, power is seen directly proportional to the nature of God's power and which is indisputable. Absolutely, political theology finds its relevance to the supremacy of power, but it is not relevant to the development of democracy. ${ }^{47}$

In the modern era, as an alternative to the model of the caliphate which was declared obsolete and impossible to revive, the idea of an Islamic state was then introduced as a form of division of theological doctrine of the caliphate. In a political perspective, the discourse of the formation of an Islamic state is an attempt to find a new formulation of a form of state whose roots can be traced mainly to the tension between the idea of the Caliphate and the concept of a nation state.

Its supporters consider that Muslims must

\footnotetext{
${ }^{46}$ Ibid., 18.

${ }^{47}$ Assyaukanie, Ideologi Islam Dan Utopi: Tiga Model Negara Demokrasi Di Indonesia. One thing that is often overlooked is that the discourse of democracy in Islam is essentially a political-relational construction and not just a matter of politics. Nevertheless, the discourse of democracy in Islam has a different starting point, which also gives rise to different conceptualizations. In the Western political tradition, democracy is the answer to the question of whether political authority must be given to one person, several people, or many people who then bring up the types of political government such as autocracy (government by one person), oligarchy (government by a handful of people), and polyarchy (government by many people). This is purely a political question. While in Islamic political discourse, democracy is a theological problem. It is the answer to the question of whether political authority must be given to God or humans, which then gives birth to models that are fundamentally different from those raised by Western discourse.
}

establish an Islamic state because the existence of Islamic law depends on the establishment of an Islamic state. And vice versa, an Islamic state will not stand tall without the enforcement of Islamic law. ${ }^{48}$ This improvisation certainly strengthens the view that religion does not provide a standard format about a sacred state.

A fundamental issue which also received sharp scrutiny was the formulation of political theories which were considered very late. ${ }^{49}$ Most developed political theories emerge when the political realities under study have declined.

The doctrine of the integration of religion and state cannot be understood as a jumble between the two so as not to create the belief that religious truth is political truth and vice versa, political truth is religious truth. State institutions, including the caliphate in the view of Islam are nothing more than a community of people who work together as servants of God in realizing His wishes and desires. ${ }^{50}$

The state is not an end in itself but only a means to realize benefit because it is very possible to take whatever form is possible to achieve that goal. Any system and rules are considered adequate if they can accommodate the benefit of humans. ${ }^{51}$ These values certainly do not depend on the formation of utopian Islamic caliphates which could never be presented in empirical reality.

The caliphate is not a religious dogma. Islam has absolutely no connection with the caliphate. The caliphate is nothing but a social construction and is therefore not sacred. In other words, the caliphate is a sociological historical experimentation.

Diverse state practices in Islam are proof that

\footnotetext{
${ }^{48}$ Abdul Halim, Aswaja: Politisi Nahdatul Ulama Perspektif Hermeneutika Gadamer (Jakarta: LP3ES, 2014), 62-63.

${ }^{49}$ Jhon L. Esposito, The Oxford Encyclopedia of the Modern Islamic World, Translated by Eva YN, et al with the title Ensiklopedi Oxford Dunia Islam Modern, Vol. IV, n.d.

${ }^{50}$ Abdullah Saeed, Islamic Thought: An Introduction, Translated by the Baitul Hikmah Translator Team, first edition (Yogyakarta: Baitul Hikmah Press, 2014).

${ }^{51}$ Abd. Rahim, 'Khalifah Dan Khilafah Menurut Al-Qur'an' Hunafa: Jurnal Studi Islamika 9, no. 1 (2012): 19.
} 
the problem of the state in Islam is a matter of ijtihad. The state is an instrument that was built to realize benefit as the highest moral principle and locus of the view of the universal will. In the modern era, as an alternative to the caliphate model which is outdated and impossible to revive. A democratic state is a realistic choice because it is in accordance with the development of modern life. In addition, a democratic state is an effort to approach human welfare in general in the form of universal human values.

\section{Conclusion}

In fact, Islam does not provide a final interpretation of the concept of the state in Islam. The universality and flexibility of Islam gives the widest possible space to be creative while remaining in the corridors of Islam.

In the treasures of Islamic thought, sociological considerations received an appreciation that is no less important than the religious texts themselves. The meaning of religion is not only theological oriented, based on religious texts.

\section{References}

Anwar, M. Syafi'i. Memperkuat Substansi Islam. "Pengantar" Dalam Abdurrahman Wahid. Islamku, Islam Anda, Islam Kita "Agama Masyarakat Negara Demokrasi."

First edition. Jakarta: The Wahid Institute, 2006.

Assyaukanie, Luthfi. Ideologi Islam Dan Utopi:

Tiga Model Negara Demokrasi Di

Indonesia. First edition. Jakarta: Freedom Institute, 2011.

al-'Awwa, Muhammad Salim. Fi Al-Nizham Al-

Siyasi Li Al-Dawlah Al-Islamiyyah. Vol.

IX. Kairo: Dar al-Syuruq, 2008.

Aziz, Abdul. Chiefdom Madinah: Salah Paham

Negara Islam. First edition. Jakarta:

Pustaka Alvabet, 2011.

Aziz, A. "Khilafah Dan Negara-Bangsa:
Pertarungan Legitimasi Yang Belum Usai." SIASAT 3, no. 2 (2019).

Azra, Azyumardi. Pergolakan Politik Islam. First edition. Jakarta: Paramadina, 1996.

Delahara, Nindhya Ayomi \& Trisnani, Asif. “AlKhilafah Al-Islamiyyah Fi Muwajahati Al-'Ilmaniyyah: Dirasah Maudhu'Iyyah Fi Tafsir Fi Dzilalil Al-Qur'an.” Studi Quranika: Jurnal Studi Quran 5, no.2 (2021).

Djazuli, H.A. Fiqh Siyasah: Implementasi Kemaslahatan Umat Dalam RambuRambu Syariah. Jakarta: n.d.

Engineer, Asghar Ali. Islam and Its Relevance to Our Age Diterjemahkan Oleh Hairus Salim HS Dengan Judul Islam Dan Pembebasan. First edition. Yogyakarta: Pustaka Pelajar, 2000.

Erlina, Fatni. "Sistem Khilafah Islamiyah Dalam Perspektif Ketatanegaraan Republik Indonesia.” Jurnal Idea Hukum 5, no. 1 (2019).

Esposito, Jhon L. The Oxford Encyclopedia of the Modern Islamic World. Translated by Eva YN, et al with the title Ensiklopedi Oxford Dunia Islam Modern, Vol. IV, n.d.

Halim, Abdul. Aswaja: Politisi Nahdatul Ulama Perspektif Hermeneutika Gadamer. First edition. Jakarta: LP3ES, 2014.

Husayn, Thaha. Al-Fitnah Al-Kubra, Utsman. Kairo: Dar al-Ma'arif, n.d.

Imarah, Muhammad. Al-Islam Wa Ushul AlHukm Li 'Ali 'Abd Al-Raziq. Vol. II. Beirut: al-Mu'assasah al-'Arabiyyah li al-Dirasat wa al-Nasyr, 1988.

- Izalah Al-Syubhat 'an Ma'ani AlMusthalahat. Vol. I. Kairo: Dar al-Salam, 2010.

Irwan, Mabroer. "Rekonstruksi Khilafah Dalam Al-Qur'an.” Al-Fanar: Jurnal Ilmu AlQur'an dan Tafsir 1, no. 1 (2018).

Jaelani, Jejen. "Kontroversi Khilafah: Islam, Negara, Dan Pancasila." Jurnal Sosioteknologi 14, no. 2 (2015). 
Jamil, M. Muhsin. Membongkar Mitos Menegakkan Nalar "Pergularan Islam Liberal Versus Islam Literal. First edition. Yogyakarta: Pustaka Pelajar, 2005.

Jati, Wasisto Raharjo. “Agama Dan Politik: Teologi Pembebasan Sebagai Arena Profetisasi Agama." Walisongo: Jurnal Penelitian Sosial Keagamaan 22, no. 1 (2014).

Kamil, Sukron. Pemikiran Politik Islam Tematik. First edition. Jakarta: Kencana, 2013.

Kuru, Ahmet T. Islam, Otoritarianisme, Dan Ketertinggalan. Jakarta: Kepustakaan Populer Gramedia, 2020.

Mathar, Moch. Qasim. Politik Islam Dalam Sorotan: Ketegangan Antara Pemikiran Dan Aksi. First edition. Makassar: Alauddin University Press, 2012.

Munfaridah, Tuti. "Kepemimpinan Dalam Islam." Wahana Akademika: Jurnal Studi Islam dan Sosial 14, no. 1 (2016).

Muqtada, Rikza. "Utopia Khilāfah Islāmiyyah: Studi Tafsir Politik Mohammed Arkoun." Jurnal Theologia 28, no.1 (2017).

Musa, Muhammad Yusuf. Nizham Al-Hukmi Fi Al-Islam: Al-Imamah Wa Riyasah Al-Ummah Wa Ma Yata 'allaq Biha Min Buhuts. Kairo: Dar al-Fikr al-'Arabi, n.d. Musyafiq, Ahmad. "Spiritualitas Kaum Fundamentalis." Walisongo: Jurnal Penelitian Sosial Keagamaan 20, no. 1 (2012).

Nashir, Haedar. Islam Syariat: Reproduksi Salafiyah Ideologis Di Indonesia. First edition. Bandung: Mizan, 2013.
al-Qardhawi, Yusuf. Al-Din Wa Al-Siyasah: Ta'shil Wa Radd Syubuhat. I. Kairo: Dar al-Syuruq, 2007.

Radjab, Syamsuddin. Syariat Islam Dalam Negara Hukum. Makassar: Alauddin University Press, 2011.

Rahim, Abd. "Khalifah Dan Khilafah Menurut AlQur'an.” Hunafa: Jurnal Studi Islamika 9, no. 1 (2012).

Saeed, Abdullah. Islamic Thought: An Introduction. Translated by the Baitul Hikmah Translator Team. First edition. Yogyakarta: Baitul Hikmah Press, 2014.

Suaedy, Ahmad. Pergulatan Pesantren Demokrasi. First edition. Yogyakarta: LkiS, 2000.

Suntana, Ija. Pemikiran Ketatanegaraan Islam. First edition. Bandung: Pustaka Setia, 2010.

al-Syahrastani, Abu al-Fath Abdul Karim bin Abi Bakr Ahmad. Al-Milal Wa Al-Nihal. Vol. I. Beirut: Dar al-Ma'arif, 1975.

Syaltut, Mahmud. Min Taujihat Al-Islam. Vol. VIII. Kairo: Dar al-Syuruq, 2004.

Syarif, Fajar. "Politicization of Religion: Religion in Political Discourse." Walisongo: Jurnal Penelitian Sosial Keagamaan 25, no. 2 (2017).

Yusdani. Fiqh Politik Muslim: Doktrin, Sejarah Dan Pemikiran. First edition. Yogyakarta: Amara Books, 2011.

Zunaih, Ahmad Iwan. "Khilafah : Sistem Pemerintahan Yang Profan." Jurnal Ummul Qura 4, no. 2 (2014). 